\title{
Plant Regeneration from Protoplasts Isolated from Callus of Taro (Colocasia esculenta Schott)
}

\author{
Kenji Murakami, Manabu Kimura and Sachiko Matsubara \\ Faculty of Agriculture, Okayama University, Tsushima-Naka, Okayama 700
}

\begin{abstract}
Summary
A system of protoplast isolation, callus formation, and plant regeneration in taro (Colocasia esculenta Schott $\mathrm{cv}$. Eguimo) was established.

1. Friable calli were induced by culturing etiolated stem segments of taro on Murashige and Skoog (MS) medium supplemented with $30 \mathrm{~g} \cdot \operatorname{liter}^{-1}$ sucrose, $2 \mathrm{mg} \cdot$ liter $^{-1}$ 2,4-D and $2 \mathrm{mg} \cdot \operatorname{liter}^{-1} 2 \mathrm{ip}$. Calli were maintained by subculturing on a fresh MS medium.

2. Protoplasts were easily isolated from suspension cells derived from the friable calli. The component of the enzyme solution for the isolation consisted of $1 \mathrm{~g} \cdot \mathrm{liter}^{-1}$ Pectolyase Y.23, $5 \mathrm{~g} \cdot$ liter $^{-1}$ Cellulase Onozuka RS, $5 \mathrm{mM}$ MES, $5 \mathrm{mM} \mathrm{CaCl}_{2} \cdot 2 \mathrm{H}_{2} \mathrm{O}$, and $0.5 \mathrm{M}$ mannitol.

3. Isolated protoplasts were cultured in the liquid media consisting of half strength MS inorganic salts, Kao and Michayluk's (1975) organic substances, various levels of NAA and BA, $0.1 \mathrm{M}$ glucose and $0.3 \mathrm{M}$ mannitol. Numerous colonies were formed in the medium containing $2 \mathrm{mg} \cdot \operatorname{liter}^{-1} \mathrm{BA}$.

4. Shoot regeneration from protoplast-derived calli occurred on solid MS medium with $0.2 \mathrm{mg} \cdot$ liter $^{-1} \mathrm{NAA}$ and $2 \mathrm{mg} \cdot$ liter $^{-1} \mathrm{BA}$. The shoots initiated roots after being transferred to a MS medium without phytohormones.

The protoplast culture system established in this study might be useful for cell fusion and electroporation of genes as an approach to breeding of taro.

Chemical names used: 2-N-MorPholino ethanesulfonic acid (MES); 1-naphthanlenacetic acid (NAA); 2.4-dichlorophenoxy acetic acid (2,4-D); N-phenylmethyl-1H-purin-6-amine (BA); N-3-methyl-2-butenyl-1H-purin-6-amine (2ip).
\end{abstract}

\section{Introduction}

Taro, Colocasia esculenta Schott, is an important vegetable crop and staple food in Asia, Africa, and in the Pacific Islands. The use of cross-breeding method has been limited in this species, because most of the cultivars are triploid and, even in diploid plants, flower initiation is very difficult. Therefore, somatic hybridization through protoplast fusion seems to be a possible means of genetic improvement. A prerequisite for a cell fusion technique is the establishment of a culture system for plant regeneration from protoplasts. However, taro is one of the most difficult crop species for

Received for publication 20 October 1993. protoplast culture. Oosawa and Takayanagi (1984) first reported culture of protoplasts isolated from taro leaf, but callus formation and plant regeneration from protoplasts have not been successful.

In monocotyledonous plants, calli or suspension cultured cells have been frequently used as a source of protoplasts. In taro, the growth of callus derived from shoot-tip was limited (Jackson et al., 1977; Nyman et al., 1983), whereas callus obtained from etiolated stem segments grew vigorously (Murakami et al., 1992). Therefore, we used calli obtained from stem segments. In the present paper, we describe a system of protoplast culture, including donor callus formation, protoplast isolation and culture, and plant regeneration. 


\section{Materials and Methods}

\section{Callus initiation and culture}

Shoot apices of taro cv. 'Eguimo' were cultured on a basal medium supplemented with 0.2 $\mathrm{mg} \cdot$ liter $^{-1}$ NAA. Etiolated stems were obtained by culturing these aseptic plantlets on the medium for $30 \sim 60$ days in the dark (Fig. 1). The basal medium consisted of inorganic salts (Murashige and Skoog (MS), 1962) plus (as mg・liter ${ }^{-1}$ ): 100 myo-inositol, 2 glycine, 0.5 nicotinic acid, 0.5 pyridoxine $\cdot \mathrm{HCl}, 0.1$ thyamine $\mathrm{HCl}, 30,000 \mathrm{su}-$ crose, and 2,000 Gelrite. Stem segments of $5 \mathrm{~mm}$ were cultured on a basal medium containing 2 mg.liter ${ }^{-1} 2,4$-D plus $2 \mathrm{mg} \cdot$ liter $^{-1} 2$ ip at $25{ }^{\circ} \mathrm{C}$ and $16 \mathrm{hr}$ daylength with a light intensity of $20 \mu$ $\mathrm{mol} \cdot \mathrm{sec}^{-1} \cdot \mathrm{m}^{-2}$ from a fluorescent light to obtain friable calli (Murakami et al., 1992). Vigorous and

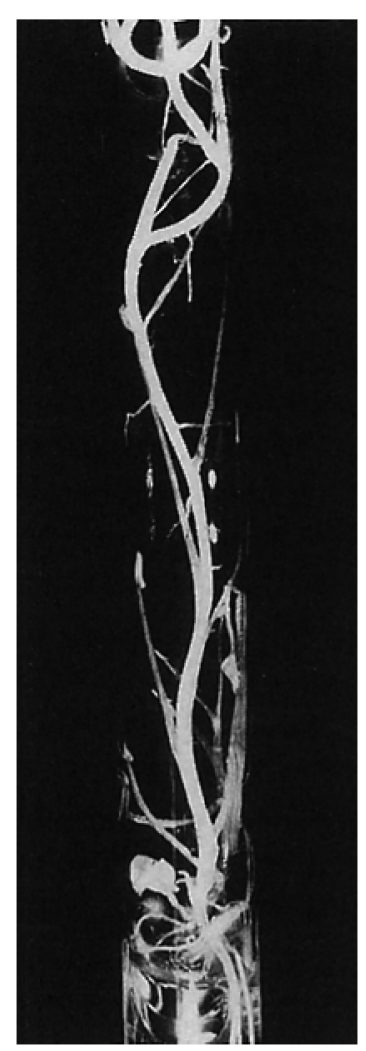

Fig. 1. Etiolated stem of taro plantlet cultured aseptically in the dark. friable calli were selected and subcultured after 60 days on a fresh medium for further prolifera. tion. Callus was then subcultured monthly on a fresh medium for 8 months.

\section{Protoplast isolation and culture}

Two to three grams of calli were cultured in a 30 -ml liquid medium containing $2 \mathrm{mg} \cdot$ liter $^{-1} 2,4$ $\mathrm{D}$ and $2 \mathrm{mg} \cdot$ liter $^{-1} 2$ ip under dim light conditions on a rotary shaker adjusted to $100 \mathrm{rpm}$ at $25^{\circ} \mathrm{C}$. Suspended cell aggregates which formed after 10 $\sim 15$ days were filtered through a $500 \mu \mathrm{m}$ mesh stainless sieve, and isolated on a $45 \mu \mathrm{m}$ stainless sieve.

These cell aggregates of $45-500 \mu \mathrm{m}$ were resuspended in a $20-\mathrm{ml}$ reaction mixture containing $1 \mathrm{~g} \cdot$ liter $^{-1}$ Pectolyase Y-23, $5 \mathrm{~g} \cdot$ liter $^{-1}$ Cellulase Onozuka RS, $5 \mathrm{mM}$ 2-N-MorPholino ethanesulfonic acid (MES), $5 \mathrm{mM} \mathrm{CaCl} \mathrm{Cl}_{2} \cdot 2 \mathrm{H}_{2} \mathrm{O}$ and $0.5 \mathrm{M}$ mannitol. The suspension was shaken on a rotary shaker adjusted to $100 \mathrm{rpm}$ for 3 hours at $25^{\circ} \mathrm{C}$. Undigested cell clumps were removed by passing the solution through a $63 \mu \mathrm{m}$ stainless sieve. The protoplasts were collected by centrifugation and washed three times with a solution of $5 \mathrm{mM} \mathrm{MES}$. $5 \mathrm{mM} \mathrm{CaCl} 2 \cdot 2 \mathrm{H}_{2} \mathrm{O}$ and $0.5 \mathrm{M}$ mannitol.

A protoplast culture medium consisting of a half strength MS inorganic salts, Kao and Michayluk's (1975) (KM) organic substances, various phytohor. mones, $0.3 \mathrm{M}$ mannitol and $0.1 \mathrm{M}$ glucose were used, because KM organic substances were found to be suitable for taro protoplast culture (Murakami and Matsubara, 1992), and shoot regeneration from callus was observed by subculturing them on MS medium supplemented with BA or with NAA and 2ip (Murakami et al., 1992). In the present study, therefore, the effects of BA and $2 \mathrm{ip}$ or the combination of NAA and BA at various concentrations were tested.

The two experiments were conducted in triplicate. In Experiment 1, isolated protoplasts were plated on media with BA or 2 ip at $0.2,2,5$ $\mathrm{mg} \cdot$ liter $^{-1}$. In Experiment 2, the protoplasts were plated on media containing $0,0.2,1$, or 5 $\mathrm{mg} \cdot$ liter $^{-1} \mathrm{NAA}$ plus $2 \mathrm{mg} \cdot \operatorname{liter}^{-1} \mathrm{BA}$. The media were sterilized by filtering through $0.2 \mu \mathrm{m}$ cellulose nitrate membranes. The isolated protoplast equivalent to $2 \times 10^{5}$ cells per $\mathrm{ml}$ were plated on $2 \mathrm{ml}$ liquid media in $60 \mathrm{~mm}$ diameter plastic petridishes. These petri-dishes were sealed with Para- 
film and kept in the dark at $25^{\circ} \mathrm{C}$ for 40 days.

Two weeks after plating, 10 microscopic fields selected at random per petri dish were examined and the plating efficiency (percent of divided cells per total number of protoplasts) was recorded.

\section{Regeneration of plant}

Calli proliferated from protoplasts on the medium supplemented with $2 \mathrm{~g} \cdot$ liter $^{-1} \mathrm{BA}$ were transferred to a basal medium containing 2 $\mathrm{mg} \cdot$ liter $^{-1}$ BA plus $0,0.2$ or $2 \mathrm{mg} \cdot$ liter $^{-1}$ NAA. Formation of green protocorm-like structures was observed 60 days later. Regenerated shoots were transferred to a basal medium without phytohormone to promote shoot growth and root formation.

\section{Results}

\section{Protoplast isolation and the plating efficiency}

The fine and friable calli which were obtained after subculturing (Fig. 2) were gradually dispersed in a liquid medium by shaking for $10-15$ days. The average yield of protoplasts was $3.8 \times$ $10^{6}$ per $g$ of callus. Considerable variation was observed in the size of protoplasts (Fig. 3), but most of them contained many small granules, similar to the protoplasts of asparagus (Elmer et al., 1989) and rice (Thomson et al., 1986) derived from suspension cells.

The tests of various levels on $\mathrm{BA}$ and $2 \mathrm{ip}$ concentrations on the plating efficiency (Exp. 1) revealed that $0.2 \mathrm{mg} \cdot$ liter $^{-1} \mathrm{BA}$ was optimum (Table 1 ), but that the subsequent colony growth on this

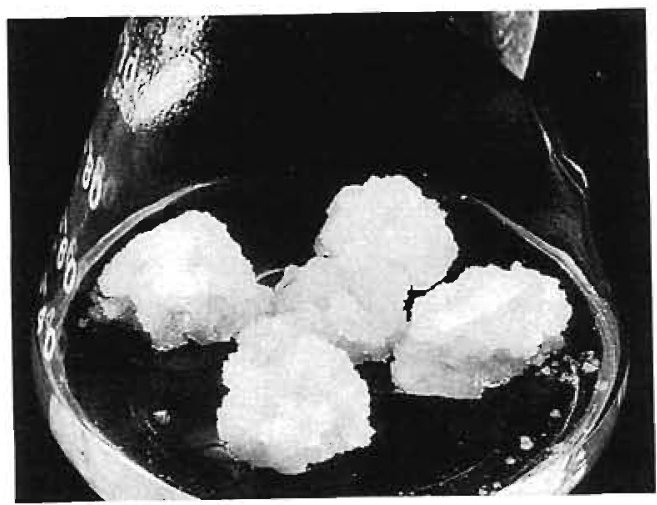

Fig. 2. Friable callus cultured on MS medium supplemented with $2 \mathrm{mg} \cdot \mathrm{liter}^{-1} 2,4-\mathrm{D}$ and $2 \mathrm{mg} \cdot$ liter $^{-1} 2$ ip. medium was poor (data not shown). Good colony growth was obtained on the medium with 2 $\mathrm{mg} \cdot$ liter $^{-1} \mathrm{BA}$. 2ip was generally less effective on plating efficiency than BA. Combining NAA at various levels with $2 \mathrm{mg} \cdot \operatorname{liter}^{-1} \mathrm{BA}$ (Exp. 2) revealed that plating efficiency slightly increased by adding $0.2 \mathrm{mg} \cdot$ liter $^{-1} \mathrm{NAA}$, compared to a medium with $2 \mathrm{mg} \cdot$ liter $^{-1} \mathrm{BA}$ alone (Table 2). However, increasing the levels of NAA lowered the efficiency.

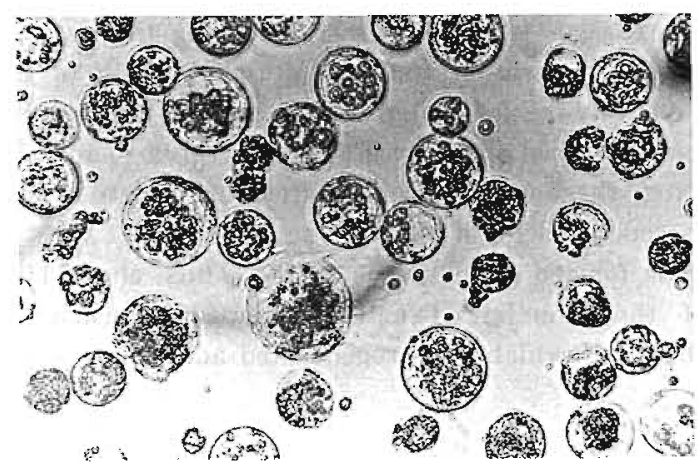

Fig. 3. Freshly isolated protoplasts.

Table 1. Effects of BA and 2ip on the division of taro pro toplasts (Experiment 1).

\begin{tabular}{|c|c|c|}
\hline \multicolumn{2}{|c|}{ Phytohormone treatment ${ }^{z}$} & Plating efficiency $y^{y}(\%)$ \\
\hline \multicolumn{3}{|c|}{$\mathrm{BA}\left(\mathrm{mg} \cdot\right.$ liter $\left.^{-1}\right)$} \\
\hline \multicolumn{2}{|r|}{0.2} & 1.6 \\
\hline \multicolumn{2}{|r|}{2.0} & 1.3 \\
\hline \multicolumn{2}{|r|}{5.0} & 0.9 \\
\hline \multicolumn{3}{|c|}{$2 \mathrm{ip}\left(\mathrm{mg} \cdot\right.$ liter $\left.^{-1}\right)$} \\
\hline \multicolumn{2}{|c|}{0.2} & 0.5 \\
\hline \multicolumn{2}{|r|}{2.0} & 0.9 \\
\hline \multicolumn{2}{|r|}{5.0} & 0.8 \\
\hline \multicolumn{3}{|c|}{$\begin{array}{l}\text { Percent of dividing cells per total protoplasts after } \\
14 \text { days of culture. }\end{array}$} \\
\hline \multicolumn{3}{|c|}{$\begin{array}{l}\text { Table 2. Effects of NAA and BA on the division of taro } \\
\text { protoplasts (Experiment } 2 \text { ). }\end{array}$} \\
\hline \multicolumn{2}{|c|}{ Phytohormone treatment } & Plating efficiency ${ }^{2}(\%)$ \\
\hline NAA & $\mathrm{BA}\left(\mathrm{mg} \cdot \operatorname{liter}^{-1}\right)$ & \\
\hline 0 & 2.0 & 2.2 \\
\hline 0.2 & 2.0 & 2.4 \\
\hline 1.0 & 2.0 & 1.4 \\
\hline 5.0 & 2.0 & 1.4 \\
\hline
\end{tabular}

see Table 1. 
Plating efficiency on the medium with $2 \mathrm{mg} \cdot$ liter $^{-1}$ BA was higher than that of the same medium in Exp. 1. This may be due to the morphological difference of donor callus between two experiments. Donor callus used for Exp. 2 was softer and more homogenous than that used for Exp. 1.

\section{Plant regeneration}

Small colonies were formed after 21 days of culture (Fig. 4) which grew to $1 \sim 2 \mathrm{~mm}$ in diameter after 40 days (Fig. 5). Green protocorm-like structures were formed after transferring the calli to solid regeneration medium. More than half of the calli on $0.2 \mathrm{mg} \cdot$ liter $^{-1} \mathrm{NAA}$ plus $2 \mathrm{mg} \cdot$ liter $^{-1}$ BA produced protocorm-like structures (Table 3). After these protocorm-like structures were trans. ferred to a fresh medium several times, $20 \%$ of them formed adventitious shoots. Thus, about $10 \%$ of the transferred calli developed adventitious shoots of which $40 \%$ regenerated additional multi-

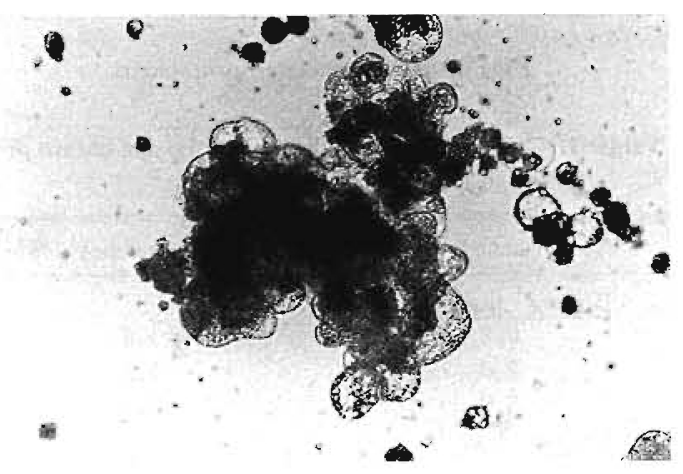

Fig. 4. Small cell aggregates after 21 days of culture.

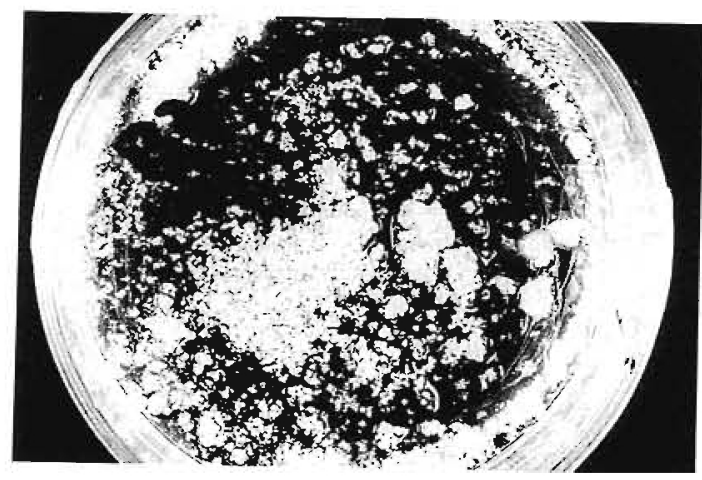

Fig. 5. Macroscopic colonies after 40 days of culture. ple shoots upon subculturing (Fig. 6). Each shoots were separated from multiple shoots and transferred to the basal medium. They grew slowly after transfer, and 3 of the 20 transferred shoots $(15 \%)$ formed roots (Fig. 7). It took almost 1 year to obtain plantlets since initial culture of protoplasts.

\section{Discussion}

The type of callus for protoplast source influences the efficiency of protoplast culture rather than the cultural conditions after the isolation (He et al., 1992; Kasem and Sagi, 1993; Morocz et al., 1990; Vasil, 1987). Callus for protoplast source is required to have the following characteristics: fast-growing, friable and regenerative. Protoplasts

Table 3. Effects of NAA and BA in subculture media on the formation of green protocorm-like structures from protoplasts-derived calli ${ }^{2}$

\begin{tabular}{lcc}
\hline \hline Phytohormone treatment & $\begin{array}{l}\text { Calli forming green } \\
\text { protocorm.like structures }(\%)\end{array}$ \\
\hline NAA & BA $\left(\mathrm{mg} \cdot\right.$ liter $\left.^{-1}\right)$ & \\
\hline 0 & 2 & 16.7 \\
0.2 & 2 & 55.6 \\
2 & 2 & 0 \\
\hline
\end{tabular}

Calli developed from protoplasts on the medium supplemented with $2 \mathrm{mg} \cdot$ liter $^{-1} \mathrm{BA}$ were used as explants.

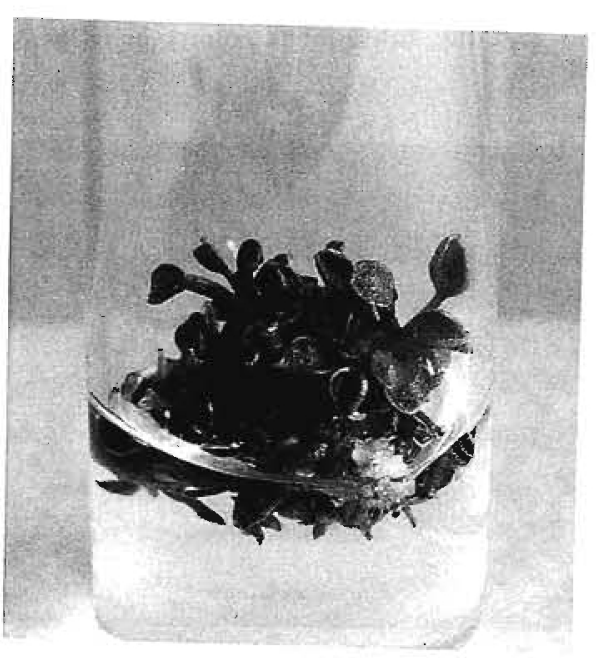

Fig. 6. Multiple-shoots regenerated from protoplast-derived callus. 


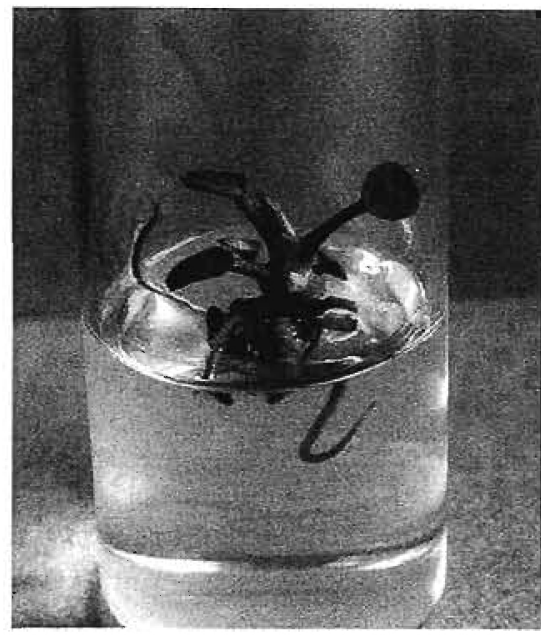

Fig. 7. A rooted plantlets after being transferred to basal medium.

isolated from fast-growing callus develop colonies at a high rate. Friable callus easily disperses in liquid medium or enzyme solution. The regenerating ability of callus is the most important character to obtain plantlets. Vasil (1987) reported that regen erative protoplasts were isolated from regenerative calli or suspension cells (Vasil, 1987). In the present study, we obtained fast-growing and friable calli which we used for isolating protoplasts Although induction of such vigorous callus from shoot-tip has been difficult, we succeeded in its in duction by using etiolated stem segments as the in itial callus explants.

Our system of protoplast culture was a simple, the protoplasts being cultured in liquid medium. Nurse culture technique, conditioned medium, agarose and other gelling agents, which were developed for the efficient protoplast culture, were not used. Nevertheless, colonies were easily developed from protoplasts in this medium which suggests that the source of the protoplasts is more important than the cultural conditions.

In the present study, however, it took an extended period to regenerate plants from protoplasts and the frequency of regeneration was low. This might be due to low regenerative ability of the callus used as protoplast source. Continuous selection of faster growing and non-regenerative callus for a long period may cause a decline of re generation ability. Such a repeated long-term sub culture also may induce gene mutations. Therefore, further study is necessary to reduce the period for callus establishment and to prevent a decline of regeneration ability. Recently, formation of embryogenic callus became possible in taro (Karube et al., 1992). Use of the embryogenic callus for protoplast source may be an approach to increase the frequency of regeneration. On the other hand, there are some reports concerning the promotion of regeneration by pretreatments of callus. For example, culturing callus in hormone-free medium promoted regeneration from protoplasts in asparagus (Kunitake and Mii, 1990) and Phalenopsis (Kobayashi et al., 1993). Thus, it would be necessary to examine various callus pretreatments for promotion of regeneration also in case of taro. By improving the frequency of plant regeneration from protoplast in the future research, the protoplast culture system described here may be applicable to the breeding of taro using the techniques such as cell fusion and electroporation.

\section{Acknowledgements}

The authors thank to Mr. Kohichi Yamamoto for his assistance in the present study.

\section{Literature Cited}

Elmer, W. H., T. Ball, M. Volokita, C. T. Stephens and K. C. Sink. 1989. Plant regeneration from callusderived protoplasts of asparagus. J. Amer. Soc. Hort. Sci. 114: 1019-1024.

He, D. G., Y. M. Yang and K. J. Scott. 1992. Plant regeneration from protoplasts of wheat (Triticum aestivum cv. Hartog). Plant Cell Reports 11 . 16-19.

Jackson, G. V. H., E. A. Ball and J. Arditti. 1977. Tissue culture of taro, Colocasia esculenta Schott. J. Hort. Sci. $52: 373-382$

Kao, K. N. and M. R. Michayluk. 1975. Nutritional requirements for growth of Vicia hajastana cells and protoplasts at a very low population density in liquid media. Planta (Berl.) $126:$ 105-110.

Karube, M., K. Shimonishi and H. Kukimura. 1992. Plant regeneration in vitro of Taro. I Embryogenesis of Taro (Colocasia esculenta cv. Egu-imo) and subsequent plantlet regeneration. Japan. J. Breed. 42 (Suppl. 2): 58-59. (In Japanese).

Kasem, Z. A. and F. Sagi. 1993. Culture of and fertile plant regeneration from regenerable embryogenic suspension cell-derived protoplasts of wheat ( $T r i$ ticum aestivum L.). Plant Cell Reports 12 175-179.

Kobayashi, S., T. Kameya and S. Ichihashi. 1993. Plant regeneration from protoplasts derived from callus 
of Phalenopsis. Plant Tissue Culture Letters 10 : 267-270.

Kunitake, H. and M. Mii. 1990. Somatic embryogenesis and plant regeneration from protoplasts of asparagus (Asparagus officinalis L.). Plant Cell Reports 8: 706-710.

Morocz, S., G. Donn, J. Nemeth and D. Duditis. 1990. An improved system to obtain fertile regenerants via maize protoplasts isolated from a highly embryogenic suspension culture. Theor. Appl. Genet. $80: 721-726$.

Murakami, K., H. Yokoyama and S. Matsubara. 1992. Callus formation and plant regeneration from etiolated stem of taro (Colocasia esculenta Schott.). J. Japan Soc. Hort. Sci. 61: 367-374. (In Japanese with English summary).

Murakami, K. and S. Matsubara. 1992. Culture of protoplast derived from callus of taro (Colocasia esculenta Schott). J. Japan Soc. Hort. Sci. 61 (Suppl. 2) : 278-279. (In Japanese).

Murashige, T. and F. Skoog. 1962. A revised medium for rapid growth and bioassays with tobacco tissue cultures. Physiol. Plant. 15 : 473-497.

Nyman, L. P., C. J. Gonzales and J. Arditti. 1983. Reversible structural changes associated with callus formation and plant development from aseptically cultured shoots of taro (Colocasia esculenta L.) Schott (Araceae). Ann. Bot. 54 : 459-466.

Oosawa, K. and K. Takayanagi. 1984. Protoplast approach in vegetable breeding I Isolation and culture of protoplasts from mesophyll cells of vegetable crops. Bull. Veg. and Ornam. Crops Res. Stn. Japan; Ser. A. 12 : 9-28. (In Japanese with English summary).

Thompson, J. A., R. Abudullah and E. C. Cocking. 1986. Protoplast culture of rice (Oryza sativa L.) using media solidified with agarose. Plant Science $47: 123-133$

Vasil, I. K. 1987. Developing cell and tissue culture system for improvement of cereal and grass crops. J. Plant Physiol. 128 : 193-218.

サトイモのカルスから単離したプロトプラストからの植物体再生

\author{
村上賢治・木村 学・松原幸子 \\ 成山大学農学部 700 岡山市津島中 1 1-1
}

摘

サトイモ（Colocasia esculenta Schott）品種·之ぐい

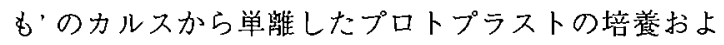
び植物体再生技術開発した。

1.プロトプラスト培盖の材料に適した巢らかいカ ルスは, 黄化菱の切片を $30 \mathrm{~g} \cdot \mathrm{iter}^{-1}$ ショ糖, 2 $\mathrm{mg} \cdot$ liter $^{-1} 2,4-\mathrm{D}+2 \mathrm{mg} \cdot \operatorname{liter}^{-1} 2$ ip および $2 \mathrm{~g} \cdot \operatorname{liter}^{-1}$ ジェランガムを添加した MS 培地で培養することによ り誘導した。このカルスは，同組成の新しい培地に継 代培養すると増殖を続けた。

2.プロトプラストは，カルスを振とう培莨して得

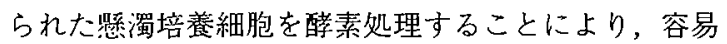
に単離された，酵素液の組成は， $1 \mathrm{~g} \cdot$ liter $^{-1}$ ペクトリ アーゼ Y-23+5 g.liter ${ }^{-1}$ セルラーゼオノズカ RS+5 $\mathrm{mM} \mathrm{MES}+5 \mathrm{mM} \mathrm{CaCl}_{2} \cdot 2 \mathrm{H}_{2} \mathrm{O}+0.5 \mathrm{M}$ マニトールとし た.

3.プロトプラストの培養は, $1 / 2$ 濃度の MS 無機

\section{要}

塩, Kao and Michayluk (1975) の有機物に, 種々の 濃度の NAA，BA，2 ip，0.1 M グルコースおよび 0.3 $\mathrm{M}$ マニトールを添加した液体培地で行った。これら のうち $2 \mathrm{mg} \cdot$ liter $^{-1} \mathrm{BA}$ を添加した培地でプロトプラス トを培盖すると多くのコロニーが形成された。

4. プロトプラスト由来のコロニーを 0.2 $\mathrm{mg} \cdot$ liter $^{-1} \mathrm{NAA}+2 \mathrm{mg} \cdot \mathrm{liter}^{-1} \mathrm{BA}$ を添加した MS 固体 培地（2 $\mathrm{g} \cdot \mathrm{liter}^{-1}$ ジェランガムで固化）に移植すると， コロニーからカルスが形成され，同組成の培地でさら に継代培養すると苗条が再生した。この苗条を切取り，

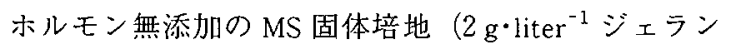
ガムで固化）で培養すると発根した。

本研究で開発されたサトイモのプロトプラスト培羑 技術は，今後再分化率の向上などを図ることによって， 細胞融合や遺伝子導入を利用した新品種育成のための, 有効な基礎技術となり得ると考えられた。 